\title{
Diaporthe species infecting sunflower in Russia
}

\author{
Maria Gomzhina*, Philipp Gannibal \\ All-Russian Institute of Plant Protection, 196608 Saint Petersburg, Russia
}

\begin{abstract}
Diaporthe is an important group of plant pathogenic fungi revealed all over the world. Early classification and species identification of this genus was mostly based on combination of morphological characteristics, cultural features, and affiliation with a host plant. According to recent investigations, valid distinction between Diaporthe species should have combined molecular techniques, morphological and cultural observations, and mating type data. In Russia a comprehensive and extensive analysis of biodiversity and geographic distribution of Diaporthe species infecting sunflower has not been performed. There were seven Diaporthe sp. strains isolated from this plant maintained in the Laboratory of Mycology and Phytopathology of All-Russian Institute of Plant Protection. In previous study a strain from Krasnodar region, based on combination of molecular and morphological features was identified as Diaporthe phaseolorum. The aim of this study was to identify all other strains using primarily molecular phylogenetic approach and traditional morphological analysis. The strains were identified as Diaporthe gulyae, Diaporthe eres, and Diaporthe helianthi. Two species - D. gulyae and D. eres are found for the first time on sunflower in Russia. Detection of $D$. helianthi is the first report of this fungus in Russia as confirmed by molecular analysis.
\end{abstract}

\section{Introduction}

Fungal species belonging to Diaporthe Nitschke are the most common and widespread fungi worldwide. This genus is extremely large and species are known as saprotrophs, endophytes, predominately phytopathogens, causing leaf and stem spots in a broad range of economically important agricultural crops, including sunflower [2]. Phomopsis stem canker is ubiquitous in many sunflower-producing regions $[3,4,5]$. This disease is one of the primary limiting factors for sunflower production in Europe, where yield losses reached up to $50 \%$ and losses in oil content exceeded $10 \%$ [4].

The pathogen causing Phomopsis stem canker on Helianthus annuus was initially described as Diaporthe helianthi Munt.-Cvetk., Mihaljc. \& M. Petrov (anamorph synonym Phomopsis helianthi Munt.-Cvetk., Mihaljc. \& M. Petrov) in the former Yugoslavia in 1980. All Diaporthe spp. isolated from infected sunflower were assumed to be D. helianthi. Although $D$. helianthi was described as the common causal agent, the possibility of multiple species infecting sunflower was raised in the early 1980s [6]. However, there was

\footnotetext{
*Corresponding author: gomzhina91@mail.ru
} 
little evidence to support this hypothesis. At that time identification of Diaporthe spp. was based on morphological and cultural features and on association with a certain host [7].

Since the description of $D$. helianthi, recent investigations [5, 8-12], employing multi-locus molecular phylogenetic approach analyses of DNA sequence data of the ITS, $\beta$-tubulin $(T U B)$, translation elongation factor- $1 \alpha(T E F)$ genes resulted in resolving additional at least 12 Diaporthe species, which together with including D. helianthi could be harmfull for sunflower.

The study of the biodiversity and geography of the Diaporthe species associated with $\mathrm{H}$. annuus in Russia according to actual taxonomy of the genus with introduction of molecular techniques just getting started. To the moment there is a single record, which has been verified by molecular phylogenetic features. This is report about Diaporthe phaseolorum (Cooke \& Ellis) Sacc. on sunflower in Krasnodar region [1]. The objective of this study was to correctly reidentify isolates of Diaporthe sp. from seeds and stems of sunflower originated from the Saint Petersburg, Belgorod and Stavropol regions.

\section{Materials and methods}

\subsection{Isolates}

Survey of 50 sunflower fields in 10 regions of Russia (Altay, Krasnodar, Stavropol territories, Belgorod, Lipetsk, Penza, Rostov, Tchelyabinsk, Tula regions and Saint Petersburg) has been conducted. Twenty-two samples of seeds derived from nine regions of Russia (Astrakhan, Orlyol, Belgorod, Tchelyabinsk, Tambov, and Volgograd regions as well as Altay, Krasnodar and Stavropol territories) has been analyzed. Six Diaporthe strains were collected from stems and seeds (table 1). To isolate a pure culture of fungus from the sunflower, fragments of material were surface sterilized with $20 \mathrm{ml}$ of $2 \%$ sodium hypochlorite $(\mathrm{NaClO})$ solution. After the surface sterilization, the samples were placed on potato sucrose agar (PSA) [13] containing antibiotics (100 $\mu \mathrm{g} / \mathrm{ml}$ ampicillin, streptomycin, penicillin, HyClone ${ }^{\mathrm{TM}}$, GE Healthcare Life Science, Austria) and $0.4 \mu \mathrm{l} / 1$ Triton X-100 (Panreac, Spain) that restricts the growth of fungi. The Petri dishes were incubated at $24^{\circ} \mathrm{C}$ in the dark and were analyzed on the 7-10th day of cultivation. Samples of infected stems were deposited in the Mycological Herbarium (LEP) of All-Russian Institute of Plant Protection (VIZR). All Diaporthe isolates were stored in plastic microtubes on PSA at + $4^{\circ} \mathrm{C}$ in the VIZR pure culture collection.

Table 1. Isolates used in this study.

\begin{tabular}{|c|c|c|c|c|}
\hline $\begin{array}{c}\text { Diaporthe } \\
\text { species }\end{array}$ & Isolate ID & $\begin{array}{c}\text { Isolation } \\
\text { source }\end{array}$ & Origin & Date of collection \\
\hline $\begin{array}{c}\text { Diaporthe } \\
\text { gulyae }\end{array}$ & $\begin{array}{c}\text { MF-Ha17-042, } \\
\text { MF-Ha17-043 }\end{array}$ & seeds & $\begin{array}{c}\text { Russia, Belgorod region } \\
\text { (center of European part) }\end{array}$ & August 2017 \\
\hline $\begin{array}{c}\text { Diaporthe } \\
\text { eres }\end{array}$ & $\begin{array}{c}\text { MF-Ha18-001, } \\
\text { MF-Ha18-002 }\end{array}$ & stems & $\begin{array}{c}\text { Russia, Saint Petersburg } \\
\text { (North West) }\end{array}$ & January 2018 \\
\hline $\begin{array}{c}\text { Diaporthe } \\
\text { helianthi }\end{array}$ & $\begin{array}{c}\text { MF-DS1, } \\
\text { MF-DS4 }\end{array}$ & seeds & $\begin{array}{c}\text { Russia, Stavropol } \\
\text { territory (South of } \\
\text { European part) }\end{array}$ & August 2018 \\
\hline
\end{tabular}




\subsection{DNA isolation, amplification and sequencing}

Mycelium was obtained from cultures incubated on PSA and macerated with $0.3 \mathrm{~mm}$ glass sand on MM400 mixer mill (Retsch, Germany). Genomic DNA was extracted according to standard CTAB/chlorophorm method [14].

Strains were screened for three loci ITS region of rDNA, TUB and TEF. The ITS region was amplified with the primers pair ITS1F [15] and ITS4 [16], the partial TUB gene with $\beta$ tub2Fw/Btub4Rd [17] and T1/T2 [18], and TEF with primers EF1-728F/EF1-986R [19], respectively. Amplicons were purified according to standard method [20]. The visualization and concentration measurement of purified PCR products were implemented by electrophoresis in 1\% agarose gel stained with ethidium bromide and MassRuler $100 \mathrm{bp}$ as a marker of concentration.

The resulting fragments were sequenced using the PCR primers together with Big Dye Terminator v3.1 Cycle Sequencing Kit (ABI, Foster City, USA) by Sanger's method (1977) [21] on ABIPrism 3500 (Applied Biosystems - Hitachi, Japan), according to the manufacturer's instructions.

Sequences were assembled using Vector NTI advance v. 11.0 (Invitrogen). Alignments of all consensus sequences, as well the reference sequences were generated with ClustalX 1.8 [22] and were improved manually when necessary. Sequences of reference Diaporthe strains and type species with Diaporthe chamaeropis (Cooke) R.R. Gomes, C. Glienke \& Crous as an outgroup were obtained from GenBank, NCBI. The phylogenetic trees were conducted in RAxML (randomized accelerated maximum likelihood) software (v. 7.2.8) [23] by Maximum likelihood (ML) method including 1000 bootstrap replicates.

\section{Results}

In all phylogenetic trees inferred from ITS, $T U B$, and $T E F$, as well in combined trees, six studied Diaporthe sp. isolates clustered in order Diaporthales, family Diaporthaceae with the highest value of bootstrap support (Fig. 1). Two strains (MF-Ha18-001, MF-Ha18-002) in a combined tree, inferred from all three loci, formed one clade with reference strains of $D$. eres Nitschke species group, but they were outside the subclade, which contain the type culture of D. eres. Whereas in the phylogram, based on TUB and TEF genes these two strains joined together in one clade, closely related to that with type D. eres.

Two strains (MF-Ha17-042, MF-Ha17-043) in the one-gene phylogenetic trees, inferred from both ITS and TEF, as well in combined tree, based on these two loci with high values of bootstrap support (100\%) clustered together with the reference strains of D. gulyae R.G. Shivas, S.M. Thompson \& A.J. Young and D. stewartii A.L. Harrison. Both these Diaporthe sp. strains in the trees, inferred from TUB genes and three gene-based phylogenetic tree clustered in the clade with the reference strain of D. gulyae. Two strains (MF-DS1, MF-DS2) in all phylogenetic trees based on single loci as well in combined trees formed the same clade with type strain of $D$. helianthi. 


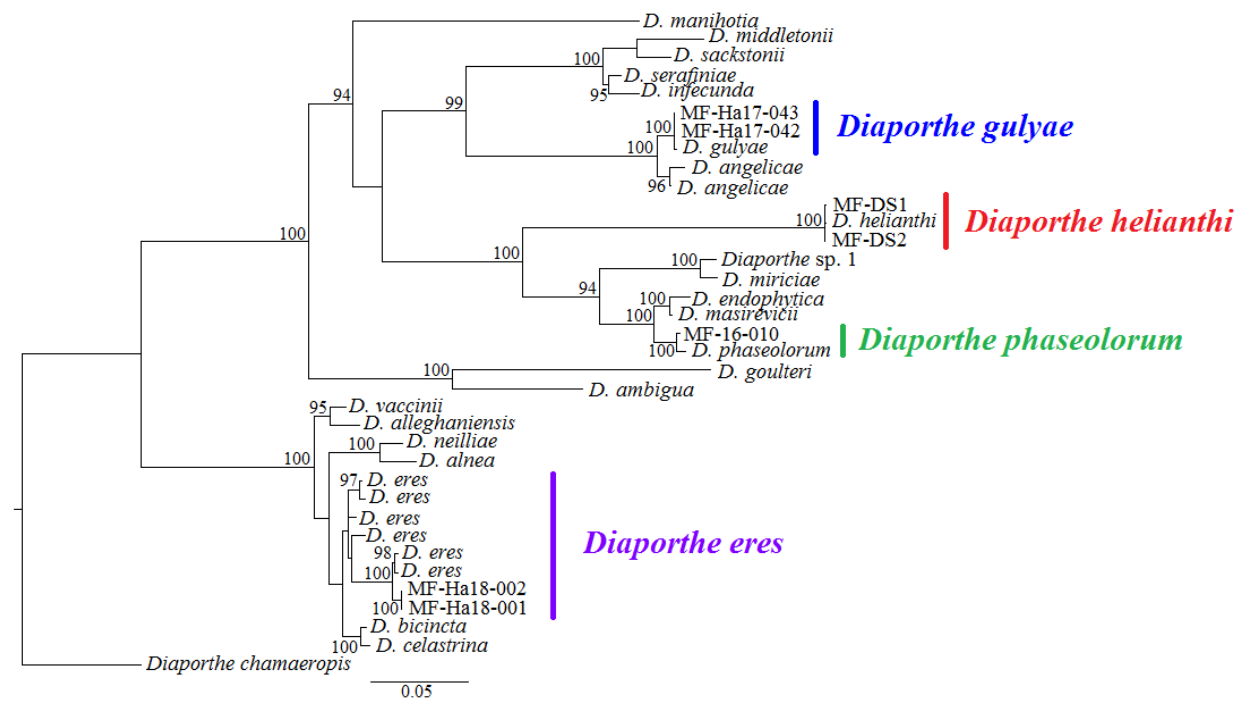

Fig.1. Maximum likelihood phylogenetic tree inferred from $T U B$ and $T E F$.

\section{Discussion}

Currently it is widely known, that species identification in Diaporthe should be implemented using a polyphasic approach (Consolidated Species Concepts (CSC)) and based on phylogenetic, morphological, and biological characteristics. A multi-locus phylogenetical analysis should be based on combined DNA data matrix of ITS and partial sequences from TUB and TEF genes.

Six Russian Diaporthe strains isolated from sunflower based on molecular phylogenetic data were identified as D. gulyae, D. eres and D. helianthi. Diaporthe gulyae was found on sunflower seed originated from Belgorod region. Diaporthe eres was detected on sunflower stems from Saint Petersburg. And finally D. helianthi, that was previously treated as the only Diaporthe species ordinary infected sunflower in Russia, was found only in Stavropol territory. Findings of two species, D. gulyae and D. eres, are the first reports of these fungi on sunflower in Russia. Detection of $D$. helianthi confirmed by molecular phylogenetic analysis is the first valid identification of this species in the country. Previous reports of $D$. helianthi have been based only on morphological features or symptoms on sunflower stems and leaves.

This work was supported by Russian Science Foundation (project \# 19-76-30005). 


\section{References}

1.M. M. Gomzhina, Ph. B. Gannibal, Microbiological independent research journal 5(1), 59-64 (2018)

2.D. Udayanga, X Liu, E. H. C. McKenzie, E. Chukeatirote, A. H. A. Bahkali, K.D. Hyde, Fungal diversity 50, 189-225 (2011)

3. T. J. Gulya, K. Y. Rashid, S. M. Masirevic, Sunflower Technology and Production (American Society of Agronomy, Madison, WI. 1997)

4. S. M. Masirevic, T. J. Gulya, Field Crops Res 30, 271-300 (1992)

5. S. M. Thompson, Y. P. Tan, A. J. Young, S. M. Neate, E. A. B. Aitken, R. G. Shivas, Persoonia 27, 80-89 (2011)

6. M. Muntañola-Cvetković, M. Mihaljčević, M. Petrov, Nova Hedwigia 34, 417-435 (1985)

7. J. C. J. van Rensburg, S. C. Lamprecht, J. Z. Groenewald, L. A. Castlebury, P. W. Crous, Stud. Mycol 55, 65-74 (2006)

8. S. M. Thompson, Y. P. Tan, R. G. Shivas, S. M. Neate, L. Morin, A. Bissett, E. A. B. Aitken, Persoonia 35, 39-49 (2015)

9.F. Mathew, K. Alananbeh, N. Balbyshev, E. Heitkamp, L. Castlebury, T. Gulya, S. Markell, Phytopathology 101, 101-115 (2011)

10. F. M. Mathew, K. M. Alananbeh, J. G. Jordah, S. M. Meyer, L. A. Castlebury, T. J. Gulya, S. G. Markell, Phytopathology 105(7), 990-997 (2015)

11. F. M. Mathew, K. Y. Rashid, T. J. Gulya, S. G. Markell, Disease notes 99(1), 160 (2015)

12. A. J. Dissanayake, E. Camporesi, K. D. Hyde, W. Zhang, J. Y. Yan, X. H. Li, Mycosphere 8(5), 853-877 (2017)

13. R. A. Samson, E. S. Hoekstra, J. C. Frisvad, O. Filtenborg, Introduction to foodand airborne fungi (Centraal bureau voor schimmel cultures, Utrecht, 2000)

14. J. J. Doyle, J. L. Doyle, Focus 12, 13-15 (1990)

15. M. Gardes, T. D. Bruns, Molecular Ecology 2, 113-118 (1993)

16. T. J. White, T. Bruns, S. Lee, J. Taylor, A guide to Methods and Applications (Academic Press, San Diego, U.S.A., 1990)

17. M. M. Aveskamp, G. J. M. Verkley, J. de Gruyter, M. A. Murace, A. Perelló, J. H. C. Woudenberg, J. Z. Groenewald, P. W. Crous, Mycologia 101(3), 363-82 (2009)

18. K. O’Donnell, E. Cigelnik, Mol Phylogenet Evol 7, 103-116 (1997)

19. I. Carbone, L. M. Kohn, Mycologia 91, 553-556 (1999)

20. J. S. Boyle, A. M. Lew, Trends Genet 11(1), 8 (1995)

21. F. Sanger, S. Nicklen, A. R. Coulson, Proceedings of the National Academy of Sciences of the U S A 74(12), 5463-5467 (1977)

22. J. D. Thompson, T. J. Gibson, F. Plewniak, F. Jeanmougin, D. G. Higgins, Nucl. Acids Res 24, 4876-4882 (1997)

23. A. Stamatakis, Bioinformatics 22, 2688-2690 (2006) 